Article

\title{
Farmers' Preferences for Genetic Resources of Kersting's Groundnut [Macrotyloma geocarpum (Harms) Maréchal and Baudet] in the Production Systems of Burkina Faso and Ghana
}

\author{
Mariam Coulibaly ${ }^{1,2}$, Chaldia O.A. Agossou ${ }^{1}$, Félicien Akohoué ${ }^{1}$, Mahamadou Sawadogo ${ }^{2}$ \\ and Enoch G. Achigan-Dako ${ }^{1, *(D)}$ \\ 1 Laboratory of Genetics, Horticulture and Seed Science, Faculty of Agronomic Sciences, University of \\ Abomey-Calavi, 01 BP 526 Abomey-Calavi, Republic of Benin; mary.coulibaly6@gmail.com (M.C.); \\ achaldia.aboegnonhou@gmail.com (C.O.A.A.); akohoue.f@gmail.com (F.A.) \\ 2 Laboratory of Biosciences, Faculty of Earth and Life Science, University of Ouaga I Pr. Joseph Ki-Zerbo, \\ 03 BP 7021 Ouagadougou, Burkina Faso; sawadogomahamadou@yahoo.fr \\ * Correspondence: enoch.achigandako@uac.bj
}

Received: 19 February 2020; Accepted: 4 March 2020; Published: 8 March 2020

\begin{abstract}
Pulses play important roles in providing proteins and essential amino-acids, and contribute to soils' nutrients cycling in most smallholder farming systems in Sub-Saharan Africa (SSA). These crops can be promoted to meet food and nutrition security goals in low-income countries. Here, we investigated the status of Kersting's groundnut (Macrotyloma geocarpum, Fabaceae), a neglected pulse in West Africa. We explored its diversity, the production systems, the production constraints and farmers' preferences in Burkina Faso and Ghana. Focus groups and semi-structured interviews were conducted in 39 villages with 86 respondents grouped in five sociolinguistic groups. Our results indicated that Macrotyloma geocarpum was produced in three cultivation systems: in the first system, farmers grew Kersting's groundnut in fields, mostly on mounds or on ridges; in the second system, farmers grew it as field border; and in the third system, no clear tillage practice was identified. The main constraints of those farming systems included: difficulty to harvest, the lack of manpower and the damage due to high soil humidity at the reproductive stage. A total of 62 samples were collected and clustered in six landraces based on seed coat colors including cream, white mottled with black eye, white mottled with greyed orange eye, black, brown mottled, and brown. All six groups were found in the southern-Sudanian zone whereas only white mottled with black eye and black colors were found in the northern-Sudanian zone. The white mottled with black eye landrace was commonly known and widely grown by farmers. Farmers' preferences were, however, influenced by sociolinguistic membership and the most preferred traits included high yielding, drought tolerance, and resistance against beetles. These findings offer an avenue to develop a relevant breeding research agenda for promoting Kersting's groundnut in Burkina Faso and Ghana.
\end{abstract}

Keywords: breeding; Macrotyloma geocarpum; farmers' preferences; cropping systems; constraints; cultivar development; landraces; conservation; sociolinguistic groups

\section{Introduction}

To feed the growing population of sub-Saharan Africa (SSA), agricultural productivity needs to be increased significantly and the existing crops diversity strengthened. The crop yield per unit area in SSA is projected to decrease [1], against an estimated increase in demand for cereals of $335 \%$ between 2010 and 2050 [2]. Similarly, the demand for legumes is also expected to increase as consumers' income 
increases with a likely shift in preferences from cereal grains to more nutrient-dense foods [3]. Moreover, the increasing world population will result in a substantial demand for additional proteins. This growing gap between demand and supply of food and nutrients in SSA will require a major re-focusing on grain legumes, with intensive research and development to identify climate-resilient species and cultivars with improved grain qualities [4]. While 19,500 species of legume were reported [5], only five are grown most widely in sub-Saharan Africa (SSA), namely common bean (Phaseolus vulgaris L.), chickpea (Cicer arietinum L.), cowpea [Vigna unguiculata (L.) Walp.], groundnut (Arachis hypogaea L.), and pigeonpea [Cajanus cajan (L.) Huth] [6]. Significant research and development work has been done in the past decade on those grain legumes through collaborative bilateral and multilateral projects as well as the CGIAR Research Program on Grain Legumes (CRP-GL) [7]. However, the bulk of edible legume species are mostly overlooked by research and development initiatives. Thus, they are often referred to as orphan legume crops. Key orphan legume crops in sub-Saharian Africa include Bambara groundnut [Vigna subterranean L. (Verdc.)], Yam bean [Sphenostylis stenocarpa (Hoechst ex. A. Rich.) Harms.)], Faba bean (Vicia faba L.) and Kersting's groundnut (Macrotyloma geocarpum).

Kersting's groundnut is an example of an orphan legume crop of West-Africa [8] with a wide spectrum of importance, for both human and animal health. The crop is valuable to human nutrition, particularly in areas where access to animal protein is limited. Its seeds have a high protein content $(21.3 \%)$ [9], carbohydrate $(61.53 \%-73.3 \%)$ and crude fibre (6.2\%) [10]. M. geocarpum is considered as healthy because its grains contain a very low crude fat $(1.0 \%)$ and a high concentration in arginine, an amino acid for pediatric growth; the seeds are also a good source of mineral elements such as iron, zinc, calcium and magnesium [9]. This crop can be used for complementary food formulation for children to combat malnutrition [11]. Moreover, it provides substantial incomes for rural population in Benin, Togo, Ghana, and Burkina Faso; its price can hike from CFA 1000 (USD 2) per kg in abundance period to CFA 4000-5000 (USD 8-10) per kg in scarcity period [12,13]. The crop also exhibits several medicinal properties and is used in traditional healthcare by local communities [13-15]. The root system of Kersting's groundnut fixes atmospheric nitrogen and improves the quality and structure of soils [16]. With climate variability and the occurrence of prolonged drought, M. geocarpum is a candidate resilient crop for sustainable cropping systems.

Kersting's groundnut production systems, and landraces diversity were documented in some West-African countries including Benin, Togo, Ghana and Nigeria [12,13,17-19]. These studies showed that its cropping systems varied across its production areas, and revealed the existence of different groups of landraces basing on the seed coat colors. However, in Burkina Faso and Ghana, research on the species has been limited to utilization [14] and the farming systems [17,19]. In both countries, M. geocarpum production systems, germplasm collection and breeding objectives have received little attention. In addition, the diversity revealed in those countries-white mottled with black eye and black in Burkina Faso [14] and white mottled with black eye, black, and brown mottled in Ghana [16,17] —is less than the diversity reported in other countries such as Benin and Togo, where authors found five landraces: white, white mottled with black eye, white mottled with yellow eye, black, and red [12]. This knowledge discrepancy/complementarity needs to be highlighted when we seek to promote Kersting's groundnut production and its genetic improvement in those countries. In other words, the identification of farmers' preferred traits is useful for breeders in developing varieties and for extension agents in appropriate choice of varieties to be popularized [20]. Furthermore, knowledge on production systems and the rationale driving farmers' practices are key requirements for guiding successful variety introduction [21]. In the production systems of Burkina Faso and Ghana, we inquire about how Kersting's groundnut production system organized, and the factors constraining or influencing its production. How does the crop diversity vary across agroecological zones and how is it managed by sociolinguistic groups? Furthermore, what are the preferred traits of farmers and how are they correlated to social factors? In this study, we seek to understand the current traditional cropping systems and analyze factors limiting M. geocarpum production for its promotion in Burkina Faso and Ghana. We assumed that: i) on-farm practices, constraints and farmers' preferences are influenced 
by sociolinguistic group membership; ii) the genetic diversity of Kersting's groundnut in Burkina Faso and Ghana is higher than findings reported by previous studies; iii) the distribution of the crop landraces varies with agro-ecological zones.

\section{Materials and Methods}

\subsection{Study Area}

The study was carried out in Burkina Faso and Ghana in West-Africa (Figure 1). Burkina Faso is a landlocked country located between latitudes $9^{\circ}$ and $15^{\circ} \mathrm{N}$, and longitudes $6^{\circ} \mathrm{W}$ and $3^{\circ} \mathrm{E}$ bordered to the north and west by Mali, to the east by Niger and to the south by Benin, Togo, Ghana and Côte d'Ivoire. It has an area of $274,200 \mathrm{~km}^{2}$. Ghana is located on the southern coast of West Africa, between latitudes $4^{\circ} 44^{\prime} \mathrm{N}$ and $11^{\circ} 11^{\prime} \mathrm{N}$ and longitudes $3^{\circ} 11^{\prime} \mathrm{W}$ and $1^{\circ} 11^{\prime} \mathrm{E}$ with an area of $238,540 \mathrm{~km}^{2}$ and limited by Burkina to the north. The study was conducted in two agroecological zones of Burkina Faso and Ghana: the northern-Sudanian (or Sudano-Sahelian) and southern-Sudanian (Sudanian). The two agroecological zones included are both characterized by the unimodal rainfall season (Table 1).

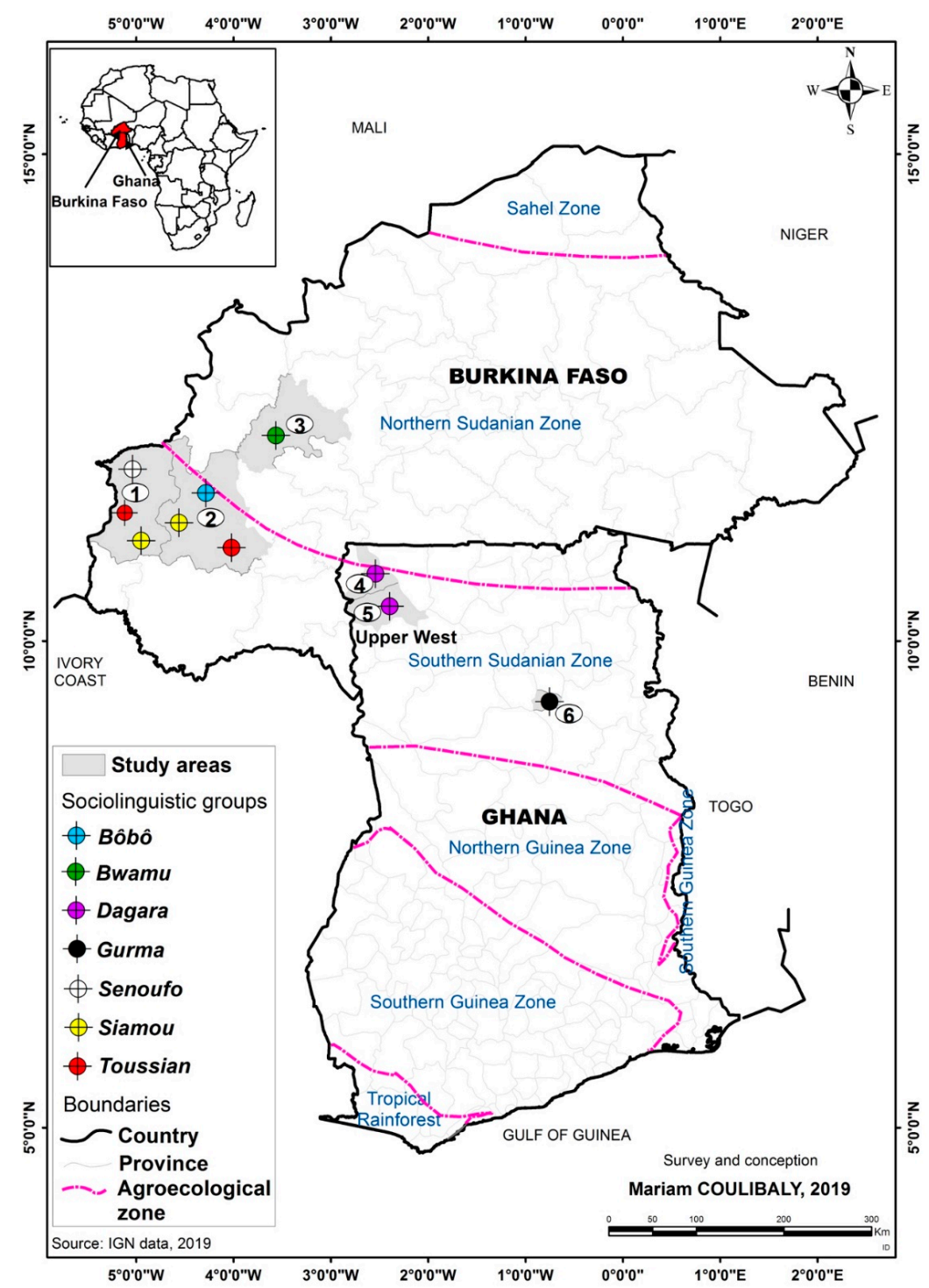

Figure 1. Study areas with agroecological zones in Burkina Faso and Ghana. 1: Kénédougou, 2: Houet, 3: Mouhoun, 4: Jirapa Lambussie, 5: Nadowli, and 6: Tamale Metropolis. 
Table 1. Characteristics of southern-Sudanian and northern-Sudanian agroecological zones of Burkina Faso and Ghana.

\begin{tabular}{|c|c|c|c|c|c|c|c|c|c|c|}
\hline \multirow[t]{2}{*}{ Country } & \multirow[t]{2}{*}{ Agroecological Zone } & \multirow[t]{2}{*}{ Latitude } & \multicolumn{4}{|c|}{ Climatic Condition } & \multicolumn{2}{|c|}{ Soil Condition } & \multirow[t]{2}{*}{ Vegetation } & \multirow[t]{2}{*}{ Cropping System } \\
\hline & & & $\begin{array}{l}\text { Growing } \\
\text { Seasons }\end{array}$ & $\begin{array}{l}\text { Rainfall } \\
\text { mm/year }\end{array}$ & $\begin{array}{l}\text { Temperature } \\
\left({ }^{\circ} \mathrm{C}\right)\end{array}$ & $\begin{array}{c}\text { Humidity } \\
(\%)\end{array}$ & Texture & Type & & \\
\hline \multirow[t]{2}{*}{$\begin{array}{l}\text { Burkina } \\
\text { Faso }\end{array}$} & Northern-Sudanian & $11^{\circ} 30^{\prime}-14^{\circ} 00^{\prime} \mathrm{N}$ & 150 days & $700-900$ & 28 & 75 & Gravel & Ferruginous & $\begin{array}{l}\text { Savanna with } \\
\text { trees or shrubs }\end{array}$ & $\begin{array}{l}\text { Cotton, sorghum, millet, cowpea, } \\
\text { groundnut }\end{array}$ \\
\hline & Southern-Sudanian & $9^{\circ} 00^{\prime}-11^{\circ} 30^{\prime} \mathrm{N}$ & $150-180$ days & $900-1200$ & 27 & 85 & Sand-clayey & Ferriferous & $\begin{array}{l}\text { Semi-deciduous } \\
\text { forest }\end{array}$ & \multirow{2}{*}{$\begin{array}{l}\text { Cotton, yams, cassava, sorghum, } \\
\text { millet, maize, rice, cowpea and } \\
\text { mangos, citrus, cashew }\end{array}$} \\
\hline Ghana & Southern-Sudanian & $8^{\circ} 00^{\prime}-11^{\circ} 30^{\prime} \mathrm{N}$ & 180-200 days & $800-1200$ & 28.1 & 61 & $\begin{array}{l}\text { Loamy sand } \\
\text { granular }\end{array}$ & Ferruginous & $\begin{array}{l}\text { Grassland with } \\
\text { few trees }\end{array}$ & \\
\hline
\end{tabular}


The northern-Sudanian zone is approximately located between latitudes $14^{\circ} 00^{\prime}$ and $11^{\circ} 30^{\prime} \mathrm{N}$, and is characterized by an annual precipitation of $600-900 \mathrm{~mm}$. The vegetation in the zone is a savanna with trees or shrubs. This zone is mainly a cotton (Gossypium hirsutum L.) production area. Other crops include sorghum [Sorghum bicolor L. (Moensch)], millet [Pennisetum glaucum (L.) R.Br.], groundnut (Arachis hypogea), and cowpea (Vigna unguiculata). In the northern-Sudanian zone, Kersting's groundnut production was limited to a few villages represented mainly by the Bwaba linguistic group of the Gur family, and representing $2.1 \%$ of the population in Burkina Faso [22].

Moving southwards, the rainfall increases to $900-1200 \mathrm{~mm}$ in southern-Sudanian zone located between latitudes $11^{\circ} 30^{\prime}$ and $9^{\circ} 00^{\prime} \mathrm{N}$ in Burkina Faso and between $8^{\circ} 00^{\prime}$ and $11^{\circ} 30^{\prime} \mathrm{N}$ in Ghana. The vegetation is characterized by a savanna with trees or shrubs, sparse forests in Burkina Faso and is made up of grassland with few trees in Ghana. Agriculture in the southern-Sudanian zone is characterized by perennial crops such as mango (Mangifera indica L.), citrus (Citrus spp.), cashew (Anacardium occidentale L.), etc. Farmers in this zone also grow cotton, cowpea, yams (Dioscorea spp.), cassava (Manihot spp.), sorghum, millet, maize (Zea mays L.), and rice (Oryza sativa L.). The Bôbô, Senufo, Siamou and Toussian of Burkina Faso and the Gurma and Dagara of Ghana are the main sociolinguistic groups producing and managing Kersting's groundnut in the southern-Sudanian zone. Senufo and Toussian groups are related to the Gur family [23] and represent respectively, $1.4 \%$ and less than $0.1 \%$ of the Burkina Faso population [22]. The Bôbô group belongs to the Mande language family and represents $1.4 \%$ of the population. The Siamou linguistic group was previously declared to belong to the Kru language family (from Ivory Coast and Liberia) [24]. The Siamou group represents $0.1 \%$ of the population of Burkina Faso [22]. These people live in the department of Orodara located in Kénédougou province. The Dagaaba and Gurma linguistic groups in Ghana belong to the Gur language family [25]. Linguistically, the Dagara are part of the Mole-Dagbane group which represents $16.6 \%$ of Ghanaians while the Gurma people represent $5.7 \%$ of the Ghanaian population.

\subsection{Sampling Strategy and Respondents' Consent}

Field trips and collection of ethnobotanical data were carried out from February to May 2018. Semi-structured interviews [26] were conducted with 86 respondents in Burkina Faso and Ghana. In each country, the investigations started by market visits to identify the sources/suppliers of Kersting's groundnut seed sellers and to get growers' contacts. The surveyed localities were identified with the help of extension agents in the regions and communities. We shared the pictures of M. geocarpum seeds, pods and plant with the focal points who identified and confirmed the growing areas of the crop in their localities. The chain-referral sampling technique [27], a non-probability sampling technique, was used in both countries to select the respondents. In this sampling, the first contact with the community was selected as a well-known expert; in a subsequent phase, the expert indicated another expert until all the informants in the community were covered. The informant was a grower who knew more about the crop, who used it and grew or used to grow it. In each surveyed locality, we explained the objectives of the study to local authorities and farmers and requested prior informed consent from all participants, and ensured participants' confidentiality by anonymizing their identities in databases and publications.

\subsection{Data Collection}

One focus group was conducted in each village. Participants included male and female farmers selected based on their willingness to participate in the study. However, in some areas, to eliminate gender dominance in discussions, separate discussions were held with men and women farmers. The focus group discussions provided an insight into the different types of landraces grown, the constraints to Kersting's groundnut production and farmers' major landrace preference criteria. The intent of this study was not to rank farmers' preference criteria but to identify the most important traits farmers seek in a variety at village level. Different seed coat colors were shown to farmers and the questionnaire was used to interview farmers who recognized and grew or used to grow the crop. 
In Ghana, the Agriculture technical services and the Savanna Agricultural Research Institute (SARI) agents also assisted the surveyors to identify the respondents in the villages by using the crop pictures and its local names.

The questionnaire was drawn up using Sphinx Plus version 4.5 [28]. For each informant, we recorded personal information about age, gender, sociolinguistic group, education level, occupation, cropland areas and the area allocated for Kersting's groundnut production. During the interviews, the respondents were requested to indicate vernacular names of the plant and the landraces they knew and the landraces they grew. Information regarding the farmers' practices and the constraints to the crop production were also recorded. Other questions were related to the criteria to choose to grow a specific landrace, and the traits of interest for the crop improvement. All interviews were conducted in the respondent's native language to ensure that questions were well understood. Local measurement units named 'tomato box', 'tine' and 'Yoruba plat' were estimated/converted in kg to determine farmers' yield of Kersting's groundnut.

In addition to interviews, seeds collection was organized with farmers who still possessed seeds of M. geocarpum. A color-chart was used to better identify the seed coat color and classify samples collected into different phenotypic groups.

\subsection{Data Analysis}

Statistical analyses of both quantitative and qualitative data were performed using $\mathrm{R}$ software version 3.6.1 [29]. Descriptive statistics were used to estimate frequencies, proportions and means for citations, socio-economic variables and Kersting's groundnut diversity data. The study areas and the diversity of Kersting's groundnut across the agroecological zones were analyzed by incorporating the germplasm collection data into a geographic information system framework to map the distribution of Kersting's groundnut diversity using ArcMap software version 10.5.

The varietal diversity analysis was performed using the farmers' knowledge, the landraces they grow and the landraces collected in the study areas. The proportion of citations of each Kersting's groundnut landrace known and landrace grown were estimated and used to calculate ratios for each sociolinguistic group.

The total number of samples per landrace collected in the two agroecological zones was calculated. In addition, ecological models were employed to analyse the level of Kersting's groundnut diversity. Following Magurran [30], we defined landrace diversity as the number of landraces collected in the study area. Based on a simple count of landraces cultivated per farmer, Margalef's and Simpson's diversity indices were computed [30]. Landraces' richness (locally adapted inter-varietal diversity) among the two agroecological zones was compared using Margalef's index $\left(\mathrm{D}_{\mathrm{Mg}}\right)$ as follows:

$$
\mathrm{D}_{\mathrm{Mg}}=(\mathrm{L}-1) / \ln (\mathrm{S})
$$

where $D_{\mathrm{Mg}}$ stands for the Kersting's groundnut diversity maintained in an agroecological zone by farmers; $L$ is the total number of Kersting's groundnut phenotypic groups or landraces collected from farmers and $S$ the total number of samples collected in an agroecological zone and $\ln$ is the natural logarithm.

The Simpson's index $(D)$ was measured to take into account the number of landraces as well as the relative abundance of each landrace. The following formula was used following Tadesse [31]:

$$
D=\sum_{i=1}^{n}(p i)^{2}
$$

where $p i$, the proportional abundance of the $i$ th landrace $=\left(n_{i} / N\right), n_{i}$ is the number of samples for the landrace $i$ and $N$ the total number of samples. As $D$ increases, the diversity decreases; consequently, the sum of the squared proportions was subtracted from $1,(1-D)$, to express the abundance of each 
landrace. The value of this index ranges between 0 and 1 ; the greater the value, the greater the phenotypic group diversity.

Furthermore, Factorial Analysis of Correspondence (FAC) was performed to assess the relationships between farmers' preferences and sociolinguistic groups. To better understand Kersting's groundnut cultivation systems, the Factorial Analysis of Mixed Data (FAMD) was used to cluster farmers' cropping practices into farming systems. Both analyses were performed using the packages FactoMineR version 2.0 [32] and factoextra version 1.0.6 [33]. Graphs were generated using ggplot2 version 3.2.1 package [34].

\section{Results}

\subsection{Socio-Demographical Characteristics of Respondents}

$60.47 \%$ of the respondents in this study were women. The respondents' age was between 27 and 103 years old with a mean value of $54.31 \pm 1.42$. Most of the respondents were illiterate $(74.42 \%)$ with farming as the main activity (75.58\%). Seven sociolinguistic groups were surveyed across the agroecological zones: Bôbô, Senufo, Siamou, Toussian, Gurma, Dagara in the southern-Sudanian zone and the Bwamu in the northern-Sudanian zone. The Dagara and Toussian were the most represented in the study with a proportion of $26.74 \%$ each. They were followed by the Bwamu (16.28\%) and the Bôbô $(12.79 \%)$ groups. Other sociolinguistic groups, with less than 10 respondents, included the Senufo (8), Siamou (5) and Gurma (2). They represented $17.44 \%$ of the total samples. The socio-demographical characteristics of the respondents are presented in the Table 2.

Table 2. Socio-demographical characteristics of respondents in southern-Sudanian and northern-Sudanian zones of Burkina Faso and Ghana.

\begin{tabular}{|c|c|c|c|c|}
\hline Variables & Modalities & Southern-Sudanian & Northern-Sudanian & Total \\
\hline Number of villages & & 28 & 11 & 39 \\
\hline Number of respondents & & 72 & 14 & 86 \\
\hline \multirow[t]{2}{*}{ Gender $(\%)$} & Male & 36.11 & 57.14 & 39.53 \\
\hline & Female & 63.89 & 42.86 & 60.47 \\
\hline \multirow[t]{3}{*}{ Age (Years \pm SE) } & & $54.43 \pm 1.53$ & $53.71 \pm 3.84$ & $54.31 \pm 1.42$ \\
\hline & $<50$ years & 38.89 & 28.57 & 37.21 \\
\hline & $\geq 50$ years & 61.11 & 71.43 & 62.79 \\
\hline \multirow[t]{2}{*}{ Marital status (\%) } & Married & 81.94 & 85.71 & 82.56 \\
\hline & Widow & 18.06 & 14.29 & 17.44 \\
\hline \multirow[t]{3}{*}{ Study degree (\%) } & Illiterate & 80.56 & 42.86 & 74.42 \\
\hline & Primary school & 13.89 & 21.43 & 15.12 \\
\hline & High school & 5.56 & 35.71 & 10.47 \\
\hline \multirow[t]{5}{*}{ Socio-linguistic groups (\%) } & Bôbô & 15.28 & 0.00 & 12.79 \\
\hline & Bwamu & 0.00 & 100 & 16.28 \\
\hline & Dagara & 31.94 & 0.00 & 26.74 \\
\hline & Toussian & 31.94 & 0.00 & 26.74 \\
\hline & Others & 20.83 & 0.00 & 17.44 \\
\hline \multirow[t]{2}{*}{ Socio-professional groups (\%) } & Farmer & 75.58 & 85.71 & 76.74 \\
\hline & Other & 24.42 . & 14.29 & 23.26 \\
\hline
\end{tabular}

\subsection{Kersting's Groundnut Diversity and Folk Description}

The vernacular names used by famers to identify M. geocarpum were relatively different across sociolinguistic groups (Table 3). The folk nomenclature of the crop landraces depended mainly on the farmers' own criteria of describing it. Therefore, the names given by farmers had different meanings to the generic names of the crops. The criterion 'seed coat color' was widely used by farmers $(84.88 \%)$ to identify Kersting's groundnut different landraces. The identification of the crop was based also on the agronomic properties $(33.72 \%)$, the seed size $(8.14 \%)$, the religious utilizations of the crop (5.81\%), and the growth habits (3.47\%). Farmers' descriptions of $M$. geocarpum referred sometimes to other legume crops, such as Bambara groundnut, because of the underground nature of both crops, and cowpea, because of their similarity in seed coat color (white mottled with black eye) and taste. 
Different local names can be assigned to the crop by the same sociolinguistic group. Furthermore, the same name can be used by different groups. For instance, the Toussian group referred to Kersting's groundnut mainly using three different names, such as Gwandjessi, Sidiin and Soonbia. The names Soonbia and Sidiin were also used by Bôbô and Siamou groups, respectively. In addition to these names, the Siamou called the crop Sissi, and the Bôbô used Zaka or Bôn to refer to the crop. The Dagara sociolinguistic group used names such as Sonsuonii and Sonsuolii, while the Gurma group referred to the crop as Susuonu. The Bwamu and Senufo groups, respectively, used Watié and Dougouvouguê as names for the crop.

Table 3. Local names of Kersting's groundnut landraces, farmers' description criteria and their characteristics across sociolinguistic groups in Burkina Faso and Ghana.

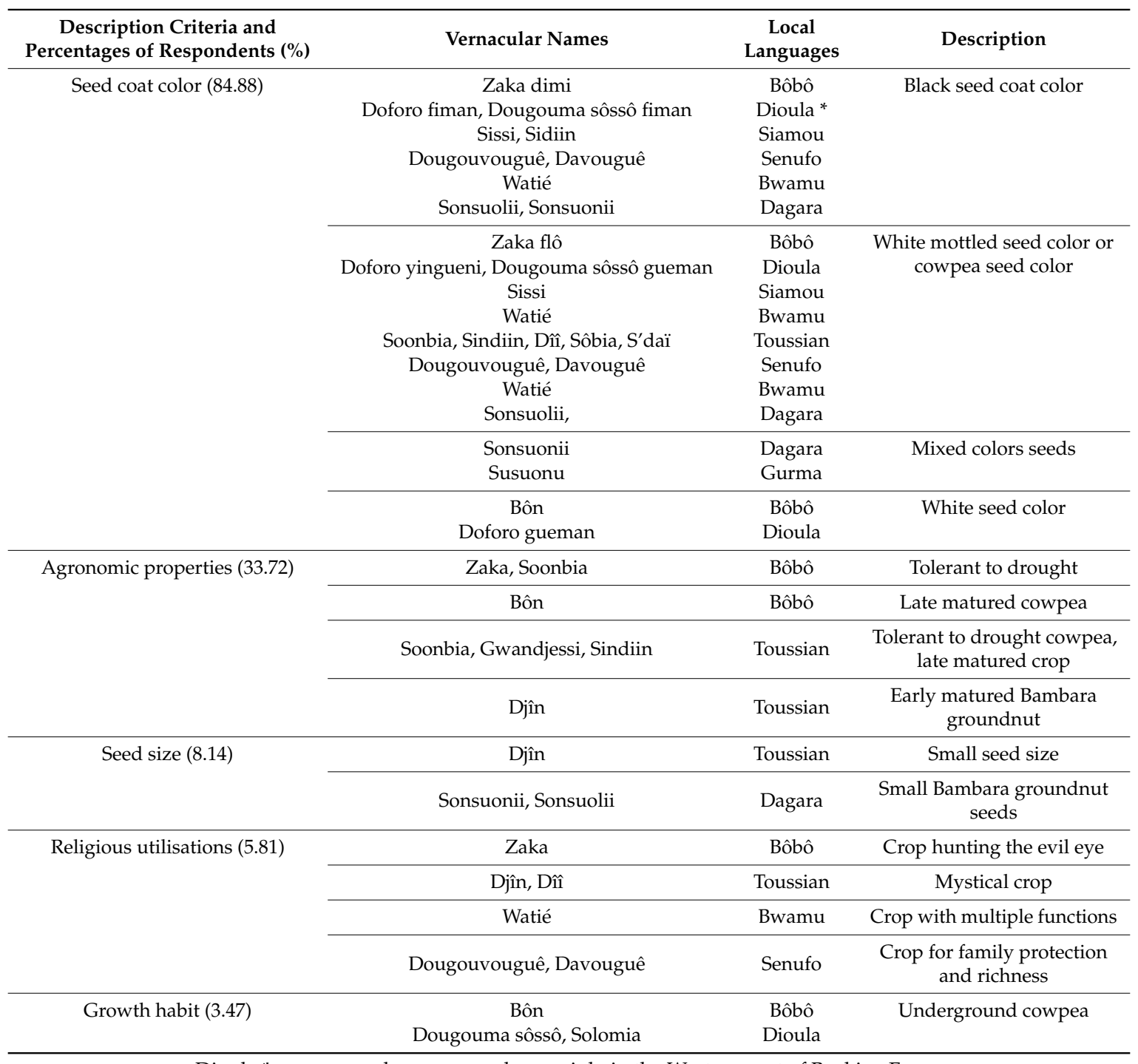

Dioula *: a common language spoken mainly in the Western part of Burkina Faso.

\subsection{Farmers' Knowledge and Extent of Kersting's Groundnut Diversity in Burkina Faso and Ghana}

According to the frequency of citations for each landrace known and grown by farmers and the ratio values, the six landraces (Figure 2) recorded across sociolinguistic groups could be arranged into four groups (Table 4). Group 1 included well-known ( $>50 \%$ of respondents) and frequently grown (ratio $>50 \%$ ) landraces; Group 2 was made up of well-known ( $>50 \%)$ but less-grown $(<50 \%)$ landraces; Group 3 was represented by less-known $(<50 \%)$ but frequently grown landraces; Group 4 included less-known and less-grown landraces. The two landraces-White mottled with black eye and 
Black - were known by all the linguistic groups; they made the Group 1 and Group 2, respectively. The White mottled with black eye was mainly adopted by the Toussian (ratio $=95.65 \%$ ) while it was less cultivated by the Bôbô (ratio $=14.29 \%$ ). Apart from the Dagara, all the linguistic groups grew the Black landrace which was widely grown by the Bwamu people. Group 3 was composed of the Brown mottled with greyed orange eye, the Brown and the white mottled with greyed orange eye landraces mostly produced by the Dagara. In fact, the landraces White mottled with greyed orange eye and the Brown were cited only by the Dagara group. The Brown mottled with greyed orange eye was mentioned by Gurma and Dagara groups in Ghana. The White landrace was the least known and the least cultivated. It is produced by some Bôbô communities in Burkina Faso, while the Toussian and other groups knew it but did not produce it. The knowledge of Kersting's groundnut landraces varied greatly across sociolinguistic groups. The Dagara were richer in terms of knowledge on M. geocarpum folk diversity while the Bwamu knew little about the wide diversity of this crop.

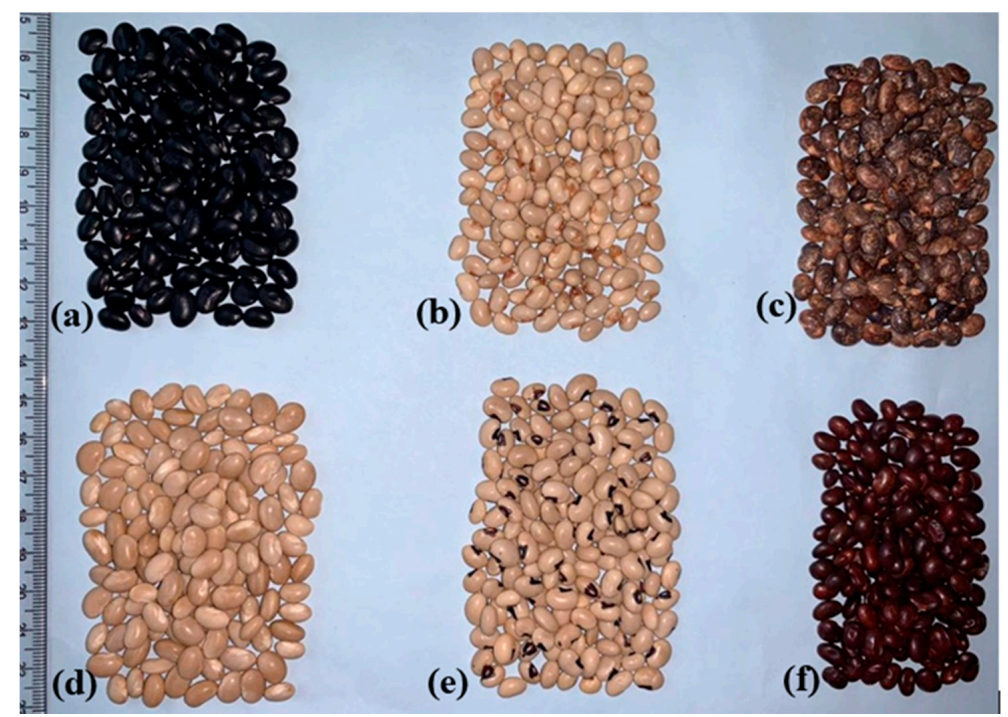

Figure 2. Kersting's groundnut seed coat colors. (a) Black, (b) White mottled with greyed orange eye, (c) Brown mottled with greyed orange eye, (d) White, (e) White mottled with black eye, (f) Brown.

Table 4. Kersting's groundnut diversity known (\%) and grown (\%) and grown/known ratios (\%) across sociolinguistic groups in Burkina Faso and Ghana. Ratio $(\%)=100 \times$ frequency of grown/frequency of known.

\begin{tabular}{|c|c|c|c|c|c|c|c|c|c|}
\hline \multirow{2}{*}{$\begin{array}{l}\text { Sociolinguistic Group } \\
\text { Landrace seed colors }\end{array}$} & \multicolumn{3}{|c|}{ Bôbô } & \multicolumn{3}{|c|}{ Bwamu } & \multicolumn{3}{|c|}{ Dagara } \\
\hline & Known & Grown & Ratio & Known & Grown & Ratio & Known & Grown & Ratio \\
\hline White & 18.18 & 9.09 & 50 & - & - & & - & - & \\
\hline White mottled with black eye & 63.64 & 9.09 & 14.29 & 35.71 & 21.43 & 60 & 17.39 & 4.35 & 25 \\
\hline $\begin{array}{l}\text { White mottled with greyed orange } \\
\text { eye }\end{array}$ & - & - & & - & - & & 4.35 & 4.35 & 100 \\
\hline Black & 90.91 & 81.82 & 90 & 100 & 100 & 100 & 73.91 & - & 0 \\
\hline Brown & - & - & & - & - & & 69.57 & 60.87 & 87.50 \\
\hline $\begin{array}{l}\text { Brown mottled with greyed orange } \\
\text { eye }\end{array}$ & - & - & & - & - & & 95.65 & 91.30 & 95.45 \\
\hline Sociolinguistic Group & \multicolumn{3}{|c|}{ Toussian } & \multicolumn{3}{|c|}{ Others } & \multicolumn{3}{|c|}{ Total } \\
\hline Landrace seed colors & Known & Grown & Ratio & Known & Grown & Ratio & Known & Grown & Ration \\
\hline White & 8.70 & - & 0 & 13.33 & - & 0 & 6.98 & 1.16 & 16.62 \\
\hline White mottled with black eye & 100 & 95.65 & 95.65 & 46.67 & 40 & 85.71 & 53.49 & 38.37 & 71.73 \\
\hline $\begin{array}{l}\text { White mottled with greyed orange } \\
\text { eye }\end{array}$ & - & - & & - & - & & 1.16 & 1.16 & 100 \\
\hline Black & 52.17 & 4.35 & 8.33 & 86.67 & 53.33 & 61.54 & 76.74 & 37.21 & 48.49 \\
\hline Brown & - & - & & - & - & & 18.60 & 16.28 & 87.5 \\
\hline $\begin{array}{l}\text { Brown mottled with greyed orange } \\
\text { eye }\end{array}$ & - & - & & 13.33 & 13.33 & 100 & 27.91 & 26.74 & 95.81 \\
\hline
\end{tabular}




\subsection{Distribution of Kersting's Groundnut Landraces and Diversity Estimation}

Landraces are the genetic bases for crop improvement. A total of 62 Kersting's groundnut samples were collected in the study districts and varied morphologically in seed coat color. The samples were clustered in six different landraces according to the seed coat color: the cream (known as White), White mottled with black eye, White mottled with grey orange eye, Black, Brown and Brown mottled with grey orange eye (Figure 2). The distribution of these groups varied across the agroecological zones. All the six landraces were found in the southern-Sudanian zone while two (i.e., White mottled with black eye and Black) were found in the northern-Sudanian zone. There were four landraces specific to the southern-Sudanian zone, while no landrace was specific to the northern-Sudanian zone. The most common and widely grown landraces listed by farmers across the two agroecological zones were the White mottled with black eye and the Black. In the southern-Sudanian zone, the six landraces comprised in total 51 samples collected, and in the northern-Sudanian zone, the two landraces found comprised 11 samples. The distribution of landraces is represented in Figure 3 and summarized in Table 5. The landraces were collected in 25 villages out of the 39 villages surveyed. In the southern-Sudanian zone samples were found in 16 villages located in six departments namely: Bôbô Dioulasso, Péni, Orodara, Kourinion, Morolaba and Jirapa. In the northern-Sudanian zone, samples were found in seven villages located in the departments of Ouarkoye and Bondokuy. Furthermore, some landraces were specific to each country. In fact, the White one was found only in Burkina Faso while the Brown, Brown mottled with greyed orange eye, and the White mottled with greyed orange eye ones were specific to Ghana.

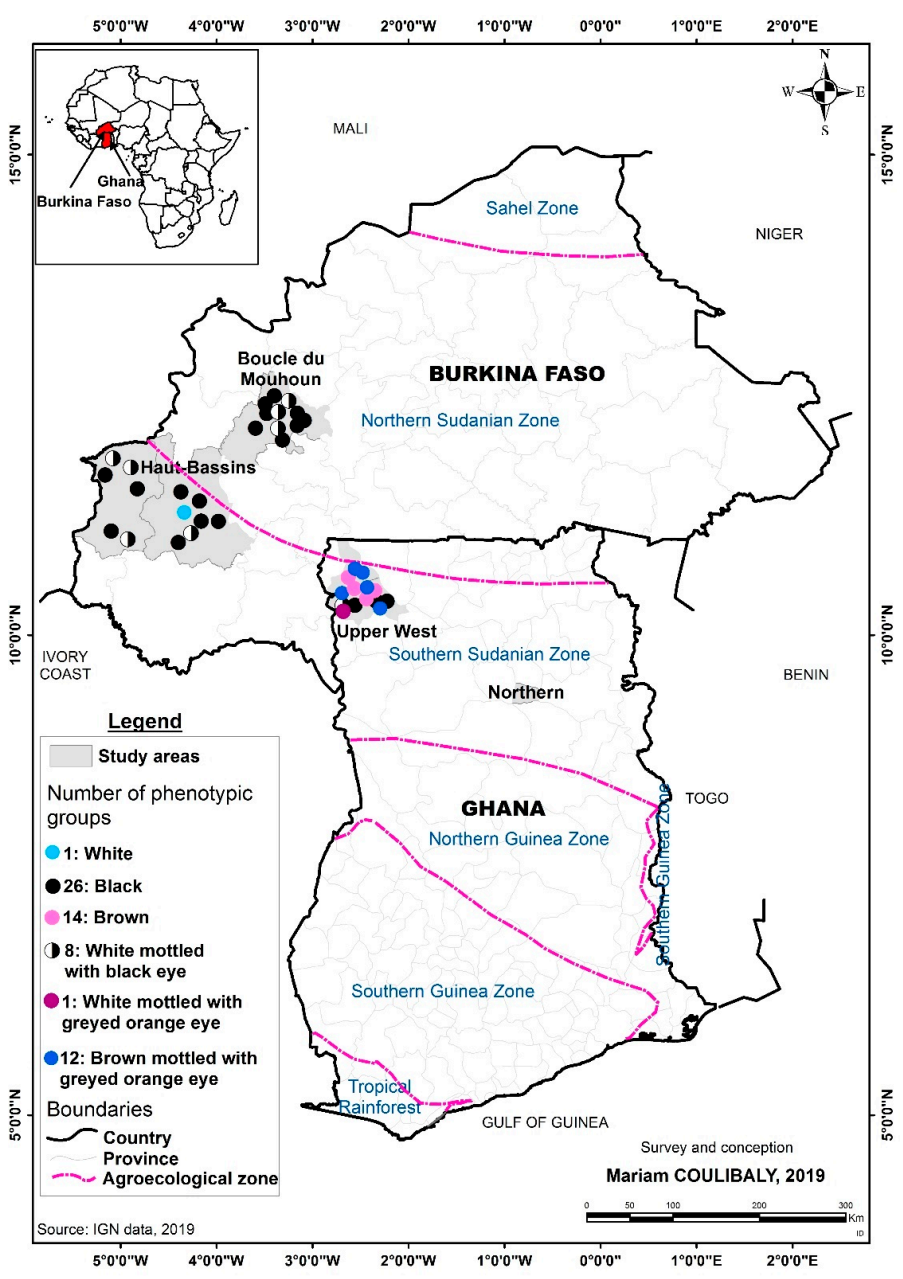

Figure 3. Distribution of Kersting's groundnut landraces collected across agroecological zones of Burkina Faso and Ghana. 
Table 5. Kersting's groundnut landraces collected with diversity indices across agroecological zones of Burkina Faso and Ghana.

\begin{tabular}{ccc}
\hline Landrace by Seed Coat Color & Southern-Sudanian & Northern-Sudanian \\
\hline White mottled with black eye & 5 & 3 \\
Black & 18 & 8 \\
White & 1 & \\
White mottled with greyed orange & 1 & \\
eye & 14 & \\
Brown & 12 & \\
Brown mottled with greyed & & 2 \\
orange eye & Diversity indices & 11 \\
& 51 & 0.42 \\
\hline Number of landraces & 1.27 & 0.40 \\
Number of samples & 0.73 & \\
Margalef's index & &
\end{tabular}

Diversity estimates (Table 5), based on the number of landraces (richness) and samples collected (abundance), revealed that the southern-Sudanian zone exhibited higher richness (Margalef $=1.27$ ) and relative abundance (Simpson $=0.73$ ) in terms of number of landraces and samples collected. The northern-Sudanian zone was found to be less diverse (Margalef $=0.42$; Simpson $=0.40$ ).

\subsection{Criteria for Choosing Kersting's Groundnut Landraces to Grow}

Farmers had many criteria in selecting M. geocarpum landraces (Table 6). These criteria concerned the crop characteristics and the use categories. The three main criteria were the seed coat color, the medicinal purposes and the organoleptic qualities. Preference for a specific landrace was dependent on the area and/or the farmer. The Black landrace was mainly grown by farmers for medicinal and socio-cultural purposes, while the White mottled with black eye landrace was grown for consumption and was preferred by farmers because of its organoleptic qualities. In other villages, the Brown and Brown mottled landraces were grown mainly because of the eating habits of consumers.

Table 6. Criteria used by farmers for growing Kersting's groundnut landraces in Burkina Faso and Ghana.

\begin{tabular}{cc}
\hline Criteria & Proportions of Citations (\%) \\
\hline Seed coat & 37.21 \\
Medicinal purposes & 33.72 \\
Organoleptic qualities & 26.74 \\
Eating habit & 24.42 \\
Socio-cultural purposes & 23.26 \\
Resistance to drought & 10.59 \\
Early maturity & 4.71 \\
\hline
\end{tabular}

\subsection{Production Systems and Management across Sociolinguistic Groups in Burkina Faso and Ghana}

In Burkina Faso and Ghana, Kersting's groundnut was produced on an average cropping area of $0.079 \pm 0.0162$ ha with an average yield of $546.10 \pm 64.30 \mathrm{Kg} / \mathrm{ha}$. Farmers in these countries grew M. geocarpum in rotation with cereals or legumes or in pure stand. However, few farmers $(4.65 \%)$ intercropped it with cereals, roselle or cassava. Another cultivation practice used by farmers was the utilization of the crop around the fields of cereals or legumes as field border. Most of the farmers adopted to grow the crop on ridges or on flat sowing, while some farmers adopted the mounds as tillage practice. Field management included weeding (21-30 days after planting) and often earthing up at the reproduction phase (45-75 days after planting) in order to facilitate the pods development. Moreover, farmers planted Kersting's groundnut between May and August during the raining season and harvested after $4-5$ months. Farmers stored the crop as dehulled seed and/or as pods in jars $(61.63 \%$ of respondents), in garrets (26.74\%), in plastic bottles (20.93\%) and in bags $(15.12 \%)$. Other material 
such as gourds, bottles and barrels were also used by a few farmers to store Kersting's groundnut. Farmers mixed Kersting's groundnut seeds with sand, ash, extracts of plants or in some rare cases with chemical products (1.16\% of respondents) to reduce beetles' attacks.

The Factorial Analysis of Mixed Data (FAMD) of the cultivation practices revealed three farming systems in Burkina Faso and Ghana (Table 7). In the first system, all farmers grew Kersting's groundnut on mounds and $92.59 \%$ of them grew it on ridges; in this system, seeds were mainly stored in garrets as dehulled seed mixed with sand. In the second system, cropping Kersting's groundnut as field border and earthing up practices were used by most of the farmers ( $90.91 \%$ and $81.82 \%$, respectively); in this system M. geocarpum was planted on flat sowing tillage and seeds were stored with plastic bottles mostly mixed with ash. In the third farming system there is no specific tillage practices; farmers in this system stored the crop as pod mixed with ash in jar.

Table 7. Results of Factorial Analysis of Mixed Data (FAMD) to cluster the cropping practices of Kersting's groundnut in Burkina Faso and Ghana.

\begin{tabular}{|c|c|c|c|c|c|}
\hline Characteristics of Systems & Cla/Mod (\%) & Mod/Cla (\%) & Global & $p$-Value & v-Test \\
\hline \multicolumn{6}{|c|}{ System 1} \\
\hline Cultivation practices $=$ field border & 9.09 & 2.38 & 12.79 & $<0.001$ & -2.81 \\
\hline Tillage $=$ ridges & 92.59 & 59.52 & 31.40 & $<0.001$ & 5.65 \\
\hline Tillage $=$ mounds & 100.00 & 19.05 & 9.30 & $<0.001$ & 3.06 \\
\hline Tillage $=$ flat sowing & 23.26 & 23.81 & 50.00 & $<0.001$ & -4.75 \\
\hline Earthing up $=$ yes & 4.55 & 2.38 & 25.58 & $<0.001$ & -5.02 \\
\hline Storage form $=$ as dehulled seed & 52.50 & 100.00 & 93.02 & $<0.001$ & 2.43 \\
\hline Storage material = garret & 73.91 & 40.48 & 26.74 & $<0.001$ & 2.76 \\
\hline Storage material $=$ plastic bottle & 22.22 & 9.52 & 20.93 & $<0.001$ & -2.50 \\
\hline Storage material = bag & 15.38 & 4.76 & 15.12 & $<0.001$ & -2.58 \\
\hline Storage product $=$ sand & 88.46 & 54.76 & 30.23 & $<0.001$ & 4.91 \\
\hline Storage product $=$ ash & 21.05 & 19.05 & 44.19 & $<0.001$ & -4.59 \\
\hline Seeds sources $=$ family & 15.79 & 7.14 & 22.09 & $<0.001$ & -3.26 \\
\hline \multicolumn{6}{|c|}{ System 2} \\
\hline Cultivation practices $=$ field border & 90.91 & 25.64 & 12.79 & $<0.001$ & 3.20 \\
\hline Cultivation practices $=$ pure stand & 31.71 & 33.33 & 47.67 & $<0.001$ & -2.38 \\
\hline Tillage $=$ flat sowing & 69.77 & 76.92 & 50.00 & $<0.001$ & 4.54 \\
\hline Tillage $=$ ridges & 3.70 & 2.56 & 31.40 & $<0.001$ & -5.53 \\
\hline Earthing up = yes & 81.82 & 46.15 & 25.58 & $<0.001$ & 3.95 \\
\hline Storage material $=$ plastic bottle & 66.67 & 30.77 & 20.93 & $<0.001$ & 1.98 \\
\hline Storage material = garret & 17.39 & 10.26 & 26.74 & $<0.001$ & -3.15 \\
\hline Storage product $=$ ash & 78.95 & 76.92 & 44.19 & $<0.001$ & 5.61 \\
\hline Storage product $=$ sand & 11.54 & 7.69 & 30.23 & $<0.001$ & -4.23 \\
\hline Seeds sources = family & 73.68 & 35.90 & 22.09 & $<0.001$ & 2.74 \\
\hline \multicolumn{6}{|c|}{ System 3} \\
\hline Storage form = pod & 100.00 & 100.00 & 5.81 & $<0.001$ & 5.55 \\
\hline Storage material $=$ jar & 15.15 & 100.00 & 38.37 & $<0.001$ & 2.71 \\
\hline Storage product $=\mathrm{ash}$ & 10.42 & 100.00 & 55.81 & $<0.001$ & 1.97 \\
\hline
\end{tabular}

$\mathrm{Cla} / \mathrm{Mod}$ : percentage of all surveyed farmers who use a specific farming practice and belong to a cluster (system). Mod/Cla: percentage of all farmers in a specific cluster (system) that also use a farming practice; $p$-value: level of analysis significance, $\mathrm{v}$-test: measures the association between variables and clusters. It reveals which variables are positively or negatively associated with the clusters.

Kersting's groundnut growers got seeds from their family as gift or heritage. Seeds used by farmers came also from their own production but also used for consumption and other utilizations.

Macrotyloma geocarpum farming systems varied significantly $(p<0.035)$ across sociolinguistic groups in Burkina Faso and Ghana (Figure 4). The Dagara (Dagari) and Toussian adopted the first and the second farming systems. The Bôbô practiced the second and third farming systems. The Bwamu practiced all three farming systems. In general, the third system was less represented in the surveyed regions while the second farming system was the most practiced by all sociolinguistic groups. 


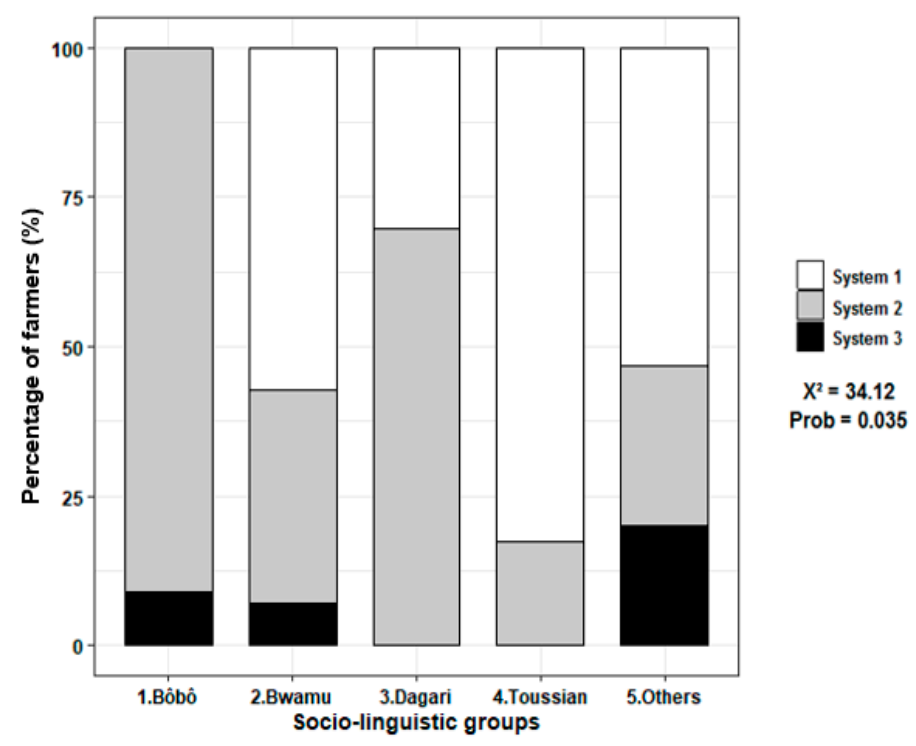

Figure 4. Frequency of Kersting's groundnut farming systems across socio-linguistic groups in Burkina Faso and Ghana.

\subsection{Bottlenecks to Kersting's Groundnut Production}

Farmers identified several factors constraining Kersting's groundnut production. Out of the fourteen cited, the five main constraints facing farmers included the difficulty to harvest the pods (66.28\% of respondents), the lack of manpower (27.91\%), the high soil moisture at the reproduction phase $(24.42 \%)$, post-harvest pests damage (23.53\%), and drought (22.09\%) (Figure 5). The non-availability of seeds and the need for intensive soil preparation were also cited by farmers as factors limiting crop production. According to them, although present, disease pressures were not a big challenge in their production system. Pests disturbing and causing damages to the crop in the field included domestic herds, rodents foraging fresh pods, and termites. Constraints varied significantly among sociolinguistic groups (Table 8). For instance, apart from the Bôbô, all the groups cited the difficulty to harvest as the main constraint they encountered. The high soil moisture during the reproductive phase was also cited by all groups apart from the Dagara. For the Bôbô, Dagara and the Toussian, drought was an important factor constraining Kersting's groundnut production. Another factor cited by producers was the non-availability of seeds limiting the production in the farming systems of Bwamu and Toussian. The post-harvest pests were ranked by the Dagara group as important constraints in Kersting's groundnut production.

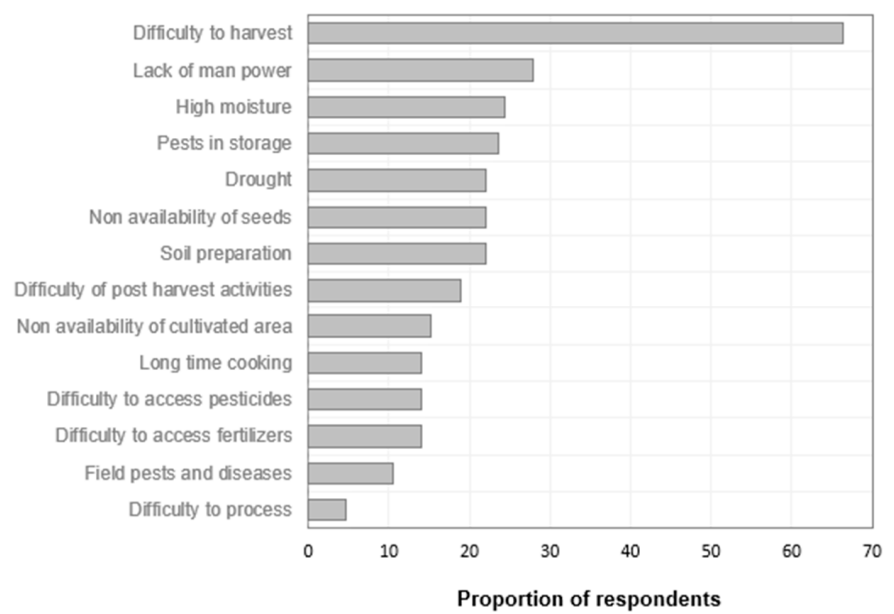

Figure 5. Constraints to Kersting's groundnut production in Burkina Faso and Ghana. 
Table 8. Proportion of citations of Kersting's groundnut production bottlenecks across sociolinguistic groups in Burkina Faso and Ghana.

\begin{tabular}{ccccccc}
\hline Constraints & Bôbô & Bwamu & Dagara & Toussian & Others & Kruskal Test \\
\hline Difficulty to harvest & 54.55 & 71.43 & 78.26 & 65.22 & 53.33 & $*$ \\
Non availability of seeds & 0.00 & 28.57 & 0.00 & 39.13 & 40.00 & $* * *$ \\
Soil preparation & 9.09 & 7.14 & 26.09 & 30.43 & 26.67 & $* *$ \\
High soil moisture & 27.27 & 28.57 & 13.04 & 34.78 & 20.00 & $*$ \\
Lack of labour & 63.64 & 14.29 & 26.09 & 30.43 & 13.33 & $* *$ \\
Pests in storage & 9.09 & 21.43 & 43.48 & 17.39 & 13.33 & $* * *$ \\
Difficulty to access fertilizers & 18.18 & 21.43 & 8.70 & 13.04 & 13.33 & $* *$ \\
Difficulty to access pesticides & 18.18 & 21.43 & 8.70 & 13.04 & 13.33 & $* *$ \\
Field pests and diseases & 27.27 & 14.29 & 0.00 & 8.70 & 13.33 & $* * *$ \\
Drought & 45.45 & 7.14 & 26.09 & 26.09 & 6.67 & $* * *$ \\
Non availability of cultivated area & 9.09 & 28.57 & 8.70 & 21.74 & 6.67 & $* * *$ \\
Difficulty of post harvesting activities & 18.18 & 21.43 & 30.43 & 13.04 & 6.67 & $* * *$ \\
Long-time cooking & 27.27 & 14.29 & 13.04 & 17.39 & 0.00 & $* * *$ \\
Difficulty to process & 18.18 & 7.14 & 4.35 & 0.00 & 0.00 & $* *$ \\
\hline
\end{tabular}

Kruskal Wallis test with frequencies of citations. ${ }^{* * *} p$ value $<0.001,{ }^{* *} p$ value $<0.01$ and ${ }^{*} p$ value $<0.05$.

\subsection{Preferred Traits for Kersting's Groundnut Improvement}

Thirteen traits were listed by producers as important for crop improvement (Table 9). The top five preferred traits included early maturing, high yielding, resistance to bruchids, tolerance to drought, and tolerance to high soil moisture. Farmers were also interested in some specific seeds' attributes, as the nutritional content and time taken to cook on available cooking facilities. White mottled with black eye and White seeded landraces were preferred by farmers and can be used as background landraces.

Table 9. Traits identified by farmers for Kersting's groundnut new varieties in Burkina Faso and Ghana.

\begin{tabular}{ccc}
\hline Criteria & Traits & Percentage of Respondents \\
\hline Agronomic & Early maturity & 34.88 \\
& High yield & 33.72 \\
Genetic resistance & Tolerance to drought & 26.74 \\
& Resistance to bruchids & 26.74 \\
& Tolerance to high soil moisture & 22.09 \\
Seeds coat colors & White seed coat & 25.58 \\
& White mottled seed coat & 25.58 \\
& Black seed coat & 18.60 \\
& Red seed coat & 10.47 \\
Seeds attributes & Brown seed coat & 8.14 \\
& Good seed quality & 15.12 \\
& Facility to cook & 10.47 \\
& Big seed size & 9.30 \\
\hline
\end{tabular}

The Factorial Analysis of Correspondence revealed variation of farmers' preferred traits across sociolinguistic groups (Figure 6). The Bôbô group preferred the black seed coat color with resistance to high soil moisture. The Bwamu were interested in short seeds cooking time. The Dagara and Toussian groups preferred the White mottled with black eye landrace with high yielding, early maturing, and big seed size attributes. 


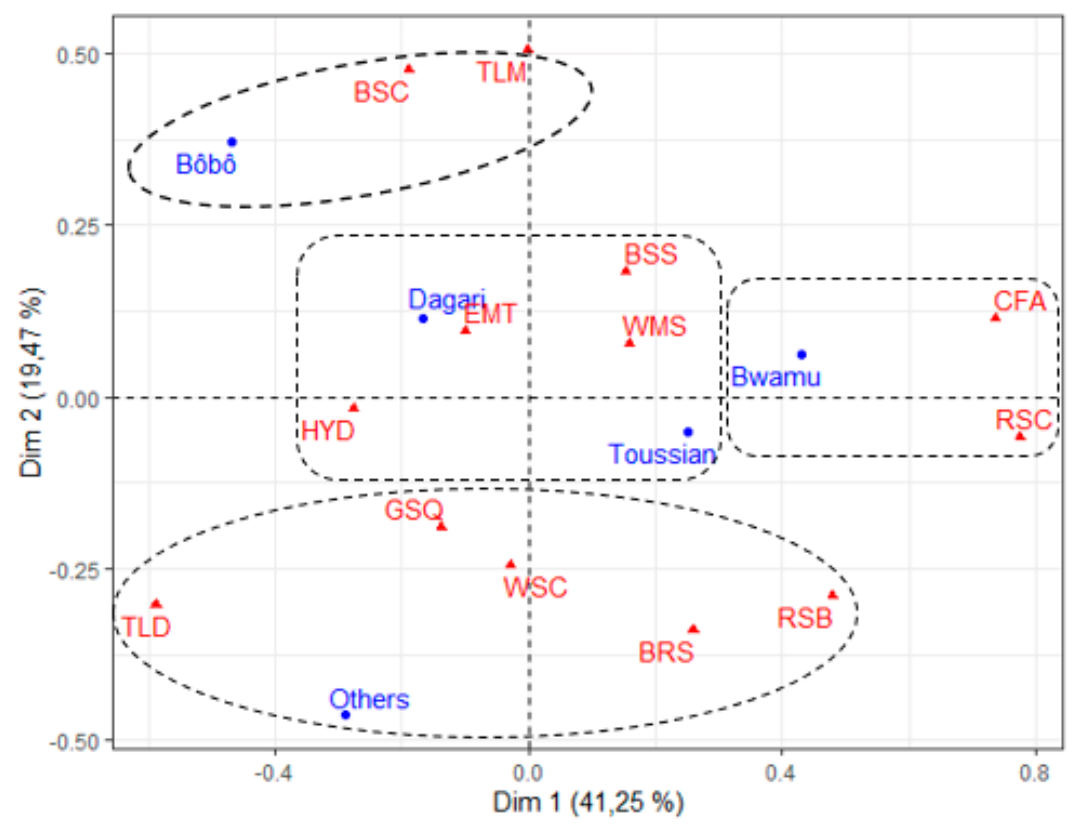

Figure 6. Traits identified by farmers for Kersting's groundnut improvement according to socio-linguistic groups. WSC: White Seed coat color; WMS: White mottled Seed coat color; RSC: Red Seed coat color; BSC: Black Seed coat color; BRS: Brown Seed coat color; TLD: Tolerance to drought; TLM: Tolerance to moisture; RSB: Resistance to bruchids; BSS: Big seed size; GSQ: Good seed quality; CFA: Facility to cook; HYD: High yield; EMT: Early maturity.

\section{Discussion}

\subsection{Knowledge, Existence and Distribution of Kersting's Groundnut Diversity in Burkina Faso and Ghana}

Sixty-two samples grouped in six different landraces were collected across both countries instead of the five landraces reported in previous studies $[12,13,17]$. Tamini $[14]$ reported the White mottled with black eye and the Black landraces in Burkina Faso; whereas in this study, a White landrace was additionally recorded and collected. Similarly, the Brown and the White mottled with greyed orange eye were found only in Ghana and were not yet reported by previous investigations $[17,35]$. In this study, we therefore found additional diversity in the southern-Sudanian zone of Burkina Faso and Ghana. Those findings support the assumption that southern-Sudanian zone can be considered as the primary center of origin of Kersting's groundnut [12]. Previous reports indicated that the crop originated from central Benin and Northern Togo [36]. Amujoyegbe [18] mentioned Nigeria as the primary center of origin of the crop. Therefore, extended investigations followed by a wide diversity resource collection is expected across other West-African countries where the cultivation of the crop was mentioned. Future explorations could involve Nigeria, Mali and Ivory Coast in order to have a clear idea of the genetic diversity of this crop and the center of origin of that diversity. This large germplasm collection should be followed by the genetic characterization in different environments in order to better understand the genetic background and the stability of Kersting's groundnut specific traits. In addition, the association studies involving molecular tools could make more accurate the genetic characterization and can be useful in the identification of QTLs of functional and economic traits. Furthermore, ex-situ conservation strategies through National and International genebanks supported by the local conservation systems must be well organized to ensure the sustainable maintenance of the existing diversity. In Benin and Togo, the Black landrace was well known by farmers but less cultivated while the White one was widely grown and well appreciated by farmers and consumers [12,13]. As noticed by Akohoué [12] in Benin and Togo, farmers in Burkina Faso and Ghana also grew the Black landrace mainly because of medicinal and socio-cultural attributes. The White and the White mottled with black eye landraces were grown mainly for consumption and their organoleptic qualities. The preference of 
farmers for these landraces represents a good opportunity for their sustainable conservation on-farm and across generations. On-farm management of agricultural biodiversity implies that smallholder farmers select and develop the species they need to match their diets, culture, markets and environment. Hence, in-situ conservation could be more organized through the valorization of Community Seed Banks (CSB). CSBs are local-level institutions that contribute to seed conservation, in particular of farmer varieties, countering erosion of crop diversity or its loss following natural disasters [37]. CSBs have been established recently in Burkina Faso and Ghana, but are limited to few regions [38]. This platform should be extended to other regions in order to limit the loss of genetic resources including Kersting's groundnut.

Landraces are considered to be an integral influence on farmers' decisions on maintenance, management, and exchange [39]. Farmers had a good knowledge of Kersting's groundnut varieties across sociolinguistic groups in terms of classification, identification, description and uses. Our results revealed that farmers go beyond just naming, by grouping landraces together based on common characters. Their indigenous knowledge would be extremely useful to agronomists, geneticists and breeders. The criteria used by farmers to describe different landraces included the seeds characteristics, agronomic and religious properties, and the growth habits of the crop. Similar results were found in other studies including on the common bean [40], fonio [41], millet [42] and Kersting's groundnut [12]. These characteristics used to identify different Kersting's groundnut landraces reflect the consistence of folk taxonomy. The seed color used by farmers as the main folk descriptor of this legume was considered as a true discriminant trait by growers as well as by scientists who performed the agro-morphological characterization of the species $[13,15,43]$.

\subsection{Kersting's Groundnut Production Systems in Burkina Faso and Ghana}

Most legumes including Kersting's groundnut have been overlooked by research and development agencies and are generally considered as women's crops in some areas since they are often produced by women producers on small land areas meant primarily for home consumption [44], whereas men tend to dominate in the production and marketing of cereals in the food value chain [45]. This was true for Kersting's groundnut in the farming systems of Burkina Faso and Ghana. However, in other communities, men were mostly involved in the crop production as the crop certainly exhibits a high economical value in those communities [12,17]. The economical and the nutritional importance of this crop should be clearly highlighted and promoted across its production areas in order to better use the genetic resources available for food and nutrition security as well as for income generation.

Farmers generally grew M. geocarpum in rotation. Others intercropped or used it as field border (mainly the Bôbô group). Farmers in Nigeria [18], Benin and Togo [12] also intercropped the crop. According to farmers, Kersting's groundnut helps improve the fertility of the soil, thereby reducing the cost of fertilizer inputs in crop farming. This is certainly due to the nodulation property of the crop for symbiotic nitrogen fixation $[16,46]$ leading to the positive contribution of legume crops in the yield improvement of associated crops [47-49].

Kersting's groundnut was grown generally on ridges or on mound in the farming systems Burkina Faso and Ghana. The same types of tillage were used in the production systems of the crop in Ghana [19], Benin and Togo [12,13,50]. The type of tillage was often different across sociolinguistic groups. In Benin, Kouelo [50] showed that the type of tillage practice can contribute significantly to improve M. geocarpum yield and was specific to the soil conditions. Therefore, investigations should be done in the different growing areas of Kersting's groundnut in order to propose to farmers the suitable tillage practice adapted to their soils' characteristics.

In Burkina Faso and Ghana, farmers stored Kersting's groundnut as pods. This practice, also reported in other countries $[12,13,17]$, contributes to limiting pulse beetles' damages and permits a longer storage life. Badii [51] found that the Black and Brown landraces were less susceptible to the bruchids (Callosobruchus maculatus Fabricius) attacks than the White mottled with black eye. The genetic determinism of this resistance to C. maculatus in Brown and Black landraces needs be 
deepened. Consequently, the possibility for introgression of bruchids-resistant gene from Brown and Black landraces into other landraces (White and White mottled with black eye) can be explored.

There was a number of barriers to M. geocarpum production, including the hard work required for harvesting while there is an increasing a lack of manpower for cultivation. In addition, the crop was grown mainly by elderly people (above 50 years old) while young people were focused on cereals and cash crops-generally ignoring legumes. This situation was also reflected by many governments' policy and research institution priorities [52]. The difficulty to harvest appeared as a major challenge for growers in Benin and Nigeria as well $[13,18]$.

Furthermore, the non-availability of seeds to meet farmers' needs is another constraint limiting Kersting's groundnut production. In fact, in most of the growing areas where the crop production was decreasing or disappeared, farmers lost their seeds and did not have the possibility of a new supply. Similarly, in Benin, the lack of market for seed supply was one of the reasons for the low production of Kersting's groundnut. The possibility for M. geocarpum commercial seeds production is still inexistent; farmers saved their own seeds for planting. At the same time, the easy access to quality seed can be achieved and guaranteed only if there is a viable seed supply system to multiply and distribute seeds that have been produced or preserved by farmers [53]. According to the same authors, the most effective alternative is to create smallholder seed enterprises, located in farming communities, with lower capital investment needs. These enterprises should be closed to smallholder farmers and be able to distribute quality seeds of improved and local varieties such as Kersting's groundnut.

\subsection{Farmers' Preferences for Kersting's Groundnut and Implication for its Genetic Improvement}

Kersting's groundnut production has been decreasing drastically because of its low yield, the small seed size and the late maturing time $[12,13,18]$. This explains the need expressed by farmers to have improved cultivars with high yield, drought tolerance, and early maturing attributes. Authors revealed that the crop exhibits variations in flowering time, seed size and grains yield [13,43]. This offers room for genetic improvement and selection of desired cultivars. However, the scarce knowledge of the reproductive biology and the narrow genetic basis [24,54], require a lot of investment to develop crosses and broaden the genetic background. Failing to establish the clear nature of Kersting's groundnut floral biology may hinder the success of its varietal improvement through the cross pollination of good landraces. Although there is room for mutagenesis, no studies have so far embraced this pathway. Mutation breeding-using both physical and chemical mutagens-has been extensively and successfully used in the development of improved cultivars of legumes such as Bambara groundnut $[55,56]$ and groundnut [57].

\section{Conclusions}

This study revealed the diversity of Kersting's groundnut landraces grown in the southern-Sudanian and northern-Sudanian zones of Burkina Faso and Ghana. Results showed that farmers grew six different landraces. All those landraces were grown in the southern-Sudanian zone, while only two were grown in the northern-Sudanian zone. Farmers preferred their varieties to be high yielding and tolerant to drought, resistant to bruchids and early maturing. This finding is relevant and important for the definition of the Kersting's groundnut breeding objectives. The study also analyzed the cropping systems of the crop, the main constraints to its production and examined farmers' preferences for its improvement. The study revealed that farming practices across the surveyed areas were diverse and strongly influenced by sociolinguistic membership. In Ghana and Burkina Faso, farmers' knowledge about the crop and its production practices remains vital for the future promotion of the resource.

Author Contributions: Conceptualization by M.C. and E.G.A.-D.; investigation by M.C. and C.O.A.A.; writing and editing M.C.; validation by E.G.A.-D., formal analysis by M.C. and F.A., review by E.G.A.-D. and M.S. All authors have read and agreed to the published version of the manuscript. 
Funding: Mariam Coulibaly, from the University of Ouaga I Prof Joseph Ki-Zerbo, Burkina Faso, was a scholar of the "Intra-Africa Academic Mobility Scheme" under the project grant number 2016-2988 on "Enhancing training and research mobility for novel crops breeding in Africa (MoBreed)" funded by the Education, Audiovisual and Culture Executive Agency (EACEA) of the European Commission. The project provided a scholarship for academic training and research mobility and a research grant to the first Author to complete a PhD degree at the University of Abomey-Calavi (Republic of Benin).

Acknowledgments: Authors wish to thank MoBreed program for the financial support. We are thankful to all farmers and agriculture technical services in Burkina Faso and Ghana. We are grateful to local authorities in all surveyed villages. We thank also Xavier Matro Comlan, Ayenan Mathieu, Dao Abdalla for all assistance during the surveys.

Conflicts of Interest: The authors declared no conflict of interest.

\section{References}

1. Alexandratos, N.; Bruinsma, J. World Agriculture Towards 2030/2050: The 2012 Revision; Food and Agriculture Organization (FAO): Rome, Italy, 2012; pp. 1-160.

2. van Ittersum, M.K.; van Bussel, L.G.J.; Wolf, J.; Grassini, P.; van Wart, J.; Guilpart, N.; Claessens, L.; de Groot, H.; Wiebe, K.; Mason-D'Croz, D.; et al. Can sub-Saharan Africa feed itself? Proc. Natl. Acad. Sci. USA 2016, 113, 14964-14969. [CrossRef] [PubMed]

3. Syngenta. The Future of Farming. 2017. Available online: http://www.syngenta-us.com/thrive/research/ future-offarming.html (accessed on 25 March 2018).

4. Considine, M.J.; Siddique, K.H.M.; Foyer, C.H. Nature's pulse power: Legumes, food security and climate change. J. Exp. Bot. 2017, 68, 1815-1818. [CrossRef] [PubMed]

5. Legume Phylogeny Working Group (LPWG). Legume phylogeny and classification in the 21st century: Progress, prospects and lessons for other species-rich clades. Taxon 2013, 62, 217-248. [CrossRef]

6. Snapp, S.; Rahmanian, M.; Batello, C. Pulse Crops for Sustainable Farms in Sub-Saharan Africa; Food and Agriculture Organization (FAO): Rome, Italy, 2018; pp. 1-60.

7. Ojiewo, C.; Monyo, E.; Desmae, H.; Boukar, O.; Mukankusi-Mugisha, C.; Thudi, M.; Pandey, M.K.; Saxena, R.K.; Gaur, P.M.; Chaturvedi, S.K.; et al. Genomics, genetics and breeding of tropical legumes for better livelihoods of smallholder farmers. Plant Breed. 2018, 138, 487-499. [CrossRef]

8. Mergeai, G. Influence des facteurs sociologiques sur la conservation des ressources phytogenetiques: Le cas de la lentille de terre [Macrotyloma geocarpum (Harms) Marechal et Baudet] au Togo. Bull. Rech. Agron. 1993, $28,487-500$.

9. Ajayi, O.B.; Oyetayo, F.L. Potentials of Kerstingiella geocarpa as a health food. J. Med. Food 2009, 12, $184-187$. [CrossRef]

10. Aremu, M.O.; Osinfade, B.G.; Basu, S.K.; Ablaku, B.E. Development and nutritional quality evaluation of Kersting's groundnut-ogi for African weaning diet. Am. J. Food Technol. 2011, 6, 1021-1033. [CrossRef]

11. Dansi, A.; Vodouhè, R.; Azokpota, P.; Yedomonhan, H.; Assogba, P.; Adjatin, A.; Loko, Y.L.; Dossou-Aminon, I.; Akpagana, K. Diversity of the neglected and underutilized crop species of importance in Benin. Sci. World J. 2012, 2012, 19. [CrossRef]

12. Akohoué, F.; Sibiya, J.; Achigan-Dako, E.G. On-Farm practices, mapping, and uses of genetic resources of Kersting's groundnut [Macrotyloma geocarpum (Harms) Maréchal et Baudet] across ecological zones in Benin and Togo. Genet. Resour. Crop Evol. 2019, 66, 195-214. [CrossRef]

13. Assogba, P.; Ewedje, E.-E.B.K.; Dansi, A.; Loko, Y.L.E.; Adjatin, A.; Dansi, M.; Sanni, A. Indigenous knowledge and agro-morphological evaluation of the minor crop Kersting's groundnut [Macrotyloma geocarpum (Harms) Maréchal et Baudet] cultivars of Benin. Genet. Resour. Crop Evol. 2015, 63, 513-529. [CrossRef]

14. Tamini, Z. Étude ethnobotanique de la Lentille de Terre [Macrotyloma geocarpum (Harms) Maréchal \& Baudet] au Burkina Faso. J. Agric. Tradit. Bot. Appliquée 1995, 37, 187-199.

15. Adu-Gyamfi, R.; Dzomeku, I.K.; Lardi, J. Evaluation of growth and yield potential of genotypes of kersting's groundnut (Macrotyloma geocarpum Harms) in Northern Ghana. Int. Res. J. Agric. Sci. Soil Sci. 2012, 2, 509-515.

16. Mohammed, M.; Jaiswal, S.K.; Sowley, E.N.K.; Ahiabor, B.D.K.; Dakora, F.D. Symbiotic N2 fixation and grain yield of endangered Kersting's groundnut landraces in response to soil and plant associated bradyrhizobium inoculation to promote ecological resource-use efficiency. Front. Microbiol. 2018, 9, 14. [CrossRef] [PubMed] 
17. Adu-Gyamfi, R.; Fearon, J.; Bayorbor, T.B.; Dzomeku, I.; Avornyo, V. The status of Kersting's groundnut [Macrotyloma Geocarpum (Harms) Marechal and Baudet]. Outlook Agric. 2011, 40, 259-262. [CrossRef]

18. Amujoyegbe, B.; Obisesan, I.O.; Ajayi, A.O.; Aderanti, F.A. Disappearance of Kersting's groundnut (Macrotyloma geocarpum (Harms) Marechal and Baudet) in South-Western Nigeria: An indicator of genetic erosion. Plant Genet. Resour. Newsl. 2007, 152, 45-50.

19. Bampuori, A.H. Effect of traditional farming practices on the yield of indigenous Kersting's groundnut (Macrotyloma geocarpum Harms) Crop in the Upper West Region of Ghana. J. Dev. Sustain. Agric. 2007, 2, 128-144.

20. Ayenan, M.A.T.; Ofori, K.; Ahoton, L.E.; Danquah, A. Pigeonpea [(Cajanus cajan (L.) Millsp.)] production system, farmers' preferred traits and implications for variety development and introduction in Benin. Agric. Food Secur. 2017, 6, 11. [CrossRef]

21. Achigan-Dako, E.G.; Adjé, C.A.; N’Danikou, S.; Hotegni, N.V.F.; Agbangla, C.; Ahanchédé, A. Drivers of conservation and utilization of pineapple genetic resources in Benin. SpringerPlus 2014, 3, 1-11. [CrossRef]

22. Ouedraogo, M. Etat et Structure de la Population: Résultats Définitifs du Recensement Général de la Population et de L'habitation (RGPH) de 2006-2009; Institut National de la Statistique et de la Démographie: Ouagadougou, Burkina Faso, 2008; pp. 1-181.

23. Traoré, D. Le senar (langue Senufo du Burkina Faso): Éléments de description et d'influence du jula véhiculaire dans un contexte de contact de langues. In Identité des Langues Gur du Burkina Faso; Delplanque, A., Ed.; Cuvillier Verlag: Göttingen, Germany, 2015; pp. 1-21.

24. Boyd, R.; Fournier, A.; Nignan, S. Une base de données informatisée transdisciplinaire de la flore chez les Seme du Burkina Faso: Un outil pour l'étude du lien nature-société. In Regards Scientifiques Croisés Sur le Changement Global et le Développement: Langue, Environnement, Culture; Delplanque, A., Ed.; The Research Institute for Development: Marseille, France, 2012; pp. 1-239.

25. van der Geest, K.A.M. The Dagara Farmer at Home and Away: Migration, Environment and Development in Ghana; Center, L.A.S., Ed.; University of Amsterdam: Amsterdam, The Netherlands, 2011; pp. 1-19.

26. Albuquerque, U.P.; de Lucena, R.F.P.; de Freitas Lins Neto, M.E. Methods and techniques used to collect ethnobiological data. In Methods and Techniques in Ethnobiology and Ethnoecology; Albuquerque, U.P., de Lucena, R.F.P., de Freitas Lins Neto, M.E., Eds.; Springer Protocols Handbooks: New York, NY, USA, 2014; pp. 1-13.

27. Albuquerque, U.P.; Cruz da Cunha, L.V.F.; Lucena, R.F.P.; Alves, R.R.N. Selection of research participants. In Methods and Techniques in Ethnobiology and Ethnoecology; Albuquerque, U.P., Cruz da Cunha, L.V.F., Lucena, R.F.P., Alves, R.R.N., Eds.; Springer Protocols Handbooks: New York, NY, USA, 2014; pp. $15-37$.

28. Sphinx Développement. Initiation au Logiciel Sphinx: De la Conception du Questionnaire à la Communication des Résultats en Passant par la Collecte des Réponses et L'analyse des Données; Sphinx Développement: Chavanod, France, 2007.

29. Team, R.C. R: A Language and Environment for Statistical Computing; R Foundation for Statistical Computing: Vienna, Austria, 2019.

30. Magurran, E. Measuring Biological Diversity; Blackwell Science Ltd.: Hoboken, NJ, USA, 2004.

31. Tadesse, D.; Asres, T. On farm diversity of barley landraces in North Western Ethiopia. Int. J. Biodivers. Conserv. 2019, 11, 1-7.

32. Le, S.; Josse, J.; Husson, F. FactoMineR: A package for multivariate analysis. J. Stat. Softw. 2008, 25, 1-18. [CrossRef]

33. Kassambara, A.; Mundt, F. Factoextra: Extract and Visualize the Results of Multivariate Data Analyses; 2019. Available online: http://www.sthda.com/english/rpkgs/factoextra (accessed on 6 March 2020).

34. Wickham, H. Ggplot2: Elegant Graphics for Data Analysis; Springer: New York, NY, USA, 2016.

35. Bayorbor, T.B.; Dzomeku, I.; Avornyo, V.; Opoku-Agyeman, M. Morphological variation in Kersting's groundnut (Kerstigiella geocarpa Harms) landraces from northern Ghana. Agric. Biol. J. N. Am. 2010, 1, 290-295. [CrossRef]

36. Achigan-Dako, E.G.; Vodouhè, S.R. Macrotyloma geocarpum (Harms) Maréchal \& Baudet. In Plant Resources of Tropical Africa 1: Cereals and Pulses; Brink, M.B.G., Ed.; Backhuys Publishers CTA, PROTA: Wageningen, The Netherlands, 2006; pp. 111-114.

37. Vernooy, R.; Shrestha, P.; Sthapit, B. The rich but little known chronicles of community seed banks. In Community Seed Banks: Origins, Evolution and Prospects; Vernooy, R., Shrestha, P., Sthapit, B., Eds.; Routeledge Taylor and Francis Group: New York, NY, USA, 2015; pp. 2-7. 
38. Vernooy, R.; Shrestha, P.; Sthapit, B. Comparative analysis of key aspects of community seed banks: Origins and evolution. In Community Seed Banks: Origins, Evolution and Prospects; Vernooy, R., Shrestha, P., Sthapit, B., Eds.; Routeledge Taylor and Francis Group: New York, NY, USA, 2015; pp. 11-19.

39. Olango, T.M.; Tesfaye, B.; Catellani, M.; Pè, M.E. Indigenous knowledge, use and on-farm management of enset (Ensete ventricosum (Welw.) Cheesman) diversity in Wolaita, Southern Ethiopia. J. Ethnobiol. Ethnomed. 2014, 10, 1-18. [CrossRef] [PubMed]

40. Loko, L.E.Y.; Toffa, J.; Adjatin, A.; Akpo, A.J.; Orobiyi, A.; Dansi, A. Folk taxonomy and traditional uses of common bean (Phaseolus vulgaris L.) landraces by the sociolinguistic groups in the central region of the Republic of Benin. J. Ethnobiol. Ethnomed. 2018, 14, 52. [CrossRef] [PubMed]

41. Ballogou, V.Y.; Mohamed, S.; Fatiou, T.; Hounhouigan, D.J. Indigenous knowledge on landraces and fonio-based food in Benin. Ecol. Food Nutr. 2014, 53, 390-409. [CrossRef]

42. Rengalakshmi, R. Folk biological classification of minor millet species in Kolli Hills, India. J. Ethnobiol. 2005, 25, 59-70. [CrossRef]

43. Akohoue, F.; Achigan-Dako, E.G.; Coulibaly, M.; Sibiya, J. Correlations, path coefficient analysis and phenotypic diversity of a West African germplasm of Kersting's groundnut [Macrotyloma geocarpum (Harms) Maréchal \& Baudet]. Genet. Resour.Crop Evol. 2019, 66, 1825-1842.

44. Mapfumo, P.; Campbell, B.M.; Mpepereki, S. Legumes in soil fertility management: The case of Pigeonpea in smallholder farming systems of Zimbabwe. Afr. Crop Sci. J. 2001, 9, 629-644. [CrossRef]

45. Bationo, A.; Waswa, B.; Okeyo, J.; Maina, F.; Kihara, J.; Mokwunye, U. Fighting Poverty in Sub-Saharan Africa: The Multiple Roles of Legumes in Integrated Soil Fertility Management; Springer: Dordrecht, The Netherlands, 2011; p. 60.

46. Mohammed, M.; Sowley, E.N.K.; Dakora, F.D. Symbiotic N 2 fixation, C assimilation and water-use efficiency (WUE) of five Rhizobium-inoculated Kersting's groundnut (Macrotyloma geocarpum) landraces measured using $15 \mathrm{~N}$ and $13 \mathrm{C}$ isotopic techniques. S. Afr. J. Bot. 2015, 98, 192-210. [CrossRef]

47. Sanou, J.; Bationo, B.A.; Barry, S.; Nabie, L.D.; Bayala, J.; Zougmore, R. Combining soil fertilization, cropping systems and improved varieties to minimize climate risks on farming productivity in northern region of Burkina Faso. Agric. Food Secur. 2016, 5, 12. [CrossRef]

48. Kalonga, J.; Mbega, E.R.; Mtei, K. Potential of legume diversification in soil fertility management and food security for resource poor farmers in Sub-Saharan Africa. J. Biodivers. Environ. Sci. JBES 2017, 11, 192-205.

49. Lupwayi, N.Z.; Kennedy, A.C.; Chirwa, R.M. Grain legume impacts on soil biological processes in sub-Saharan Africa. Afr. J. Plant Sci. 2011, 5, 1-7.

50. Kouelo, K.A.F.; Badou, A.; Houngnandan, P.; Francisco Merinosy, M.F.; Gnimassoun, C.J.-B.; Sochime, D.J. Impact du travail du sol et de la fertilisation minérale sur la productivité de Macrotyloma geocarpum (Harms) Maréchal et Baudet au center du Bénin. J. Biosci. 2012, 51, 3625-3632.

51. Badii, K.B.; Asante, S.K.; Bayorbor, T.B. Susceptibility of some Kersting's groundnut landrace cultivars to infestation by Callosobruchus maculatus (Fab.) [Coleoptera: Bruchidae]. J. Sci. Technol. 2011, 31, 10. [CrossRef]

52. Isaacs, K.B.; Snapp, S.S.; Kelly, J.D.; Chung, K.R. Farmer knowledge identifies a competitive bean ideotype for maize-bean intercrop systems in Rwanda. Agric. Food Secur. 2016, 5, 15. [CrossRef]

53. Neate, P.J.H.; Guei, R.G. Promoting the Growth and Development of Smallholder Seed Enterprises for Food Security Crops: Best Practices and Options for Decision Making; Food and Agriculture Organization (FAO): Rome, Italy, 2010; p. 28.

54. Pasquet, R.S.; Mergeai, G.; Baudoin, J.-P. Genetic diversity of the African geocarpic legume Kersting's groundnut, Macrotyloma geocarpum (Tribe Phaseoleae: Fabaceae). Biochem. Syst. Ecol. 2002, 30, 943-952. [CrossRef]

55. Adebola, M.I.; Esson, A.E. Fast neutrons induced genetic variability on Bambara nut (Vigna subterranean (L.) Verdc.). Horticult. Biotechnol. Res. 2017, 3, 10-12.

56. Chitti, B. Genetic improvement of Bambara Groundnut (Vigna subterranea (L.) Verdc) through Mutation Breeding, in Genetics and Plant Breeding; University of Agricultural Sciences GKVK: Bengaluru, India, 2015; p. 121.

57. Janila, P.; Nigam, S.N.; Pandey, M.K.; Nagesh, P.; Varshney, R.K. Groundnut improvement: Use of genetic and genomic tools. Front. Plant Sci. 2013, 4, 23. [CrossRef]

(C) 2020 by the authors. Licensee MDPI, Basel, Switzerland. This article is an open access article distributed under the terms and conditions of the Creative Commons Attribution (CC BY) license (http://creativecommons.org/licenses/by/4.0/). 